\title{
The northeastern end of the Dunnage Zone in Newfoundland
}

\author{
Kenneth L. Currie \\ Geological Survey of Canada, 601 Booth Street, Ottowa, Ontario KIA OE8, Canada
}

Date Received March 29, 1995

Date Accepted May 26, 1995

\begin{abstract}
The northeastern end of the Dunnage Zone comprises the Notre Dame Subzone, bounded to the southeast by the Red Indian Line, and the Exploits Subzone bounded to the southeast by the GRUB Line, the boundary of the Dunnage Zone against the Gander Zone. The Notre Dame Subzone consists of diverse, fault-bounded assemblages of Arenig and older rocks emplaced in oceanic settings. The Exploits Subzone includes four fault-bounded belts distinguished by their Silurian stratigraphies (Badger, Botwood, Duder [new] and Indian Islands belts). All exhibit Ashgill-Llandovery, southeast-vergent sinistral thrusting which emplaced a fragment of the Botwood Belt on the Indian Islands Belt. Progressive post-Wenlock Silurian deformation produced dextral faults and upright folds east of the Dog Bay Line, a Silurian terrane boundary, whereas west of the line it produced northwest-vergent folds. Late Silurian to Devonian brittle sinistral motion modified the Red Indian and GRUB lines. Structural and stratigraphic observations suggest early Arenig obduction of the margin of the Exploits Subzone onto the Gander Zone followed by eastward subduction of old ocean crust (Notre Dame Subzone), along the Red Indian Line, produced a west-facing volcanic arc. Arc rifting in late Arenig time produced an active back-arc basin. Rapid basin filling and structural inversion, accompanied by eastward thrusting began in Ashgill time, probably due to arrival of Laurentia at the subduction zone. Remnants of the back-arc basin were closed by westward subduction in Llandovery and Wenlock time. Continent-continent contact, accompanied by further compression and extrusion of wedge-shape fragments between conjugate faults, occurred in late Silurian time.
\end{abstract}

L'extrémité nord-est de la zone de Dunnage englobe la sous-zone de Notre-Dame, délimitée au sud-est par la ligne Red Indian, et la sous-zone d'Exploits, délimitée au sud-est par la ligne GRUB, qui délimite la zone de Dunnage contre la zone de Gander. La sous-zone de Notre-Dame est constituée des assemblages variés limités par des failles de la série Arenig et les roches plus âgées placées dans des milieux océaniques. La sous-zone d'Exploits comprend quatre ceintures limitées par des failles qui se distinguent par leurs stratigraphies du Silurien (ceintures de Badger, de Botwood, de Duder [nouvelle] et des îles Indian). Toutes exposent les séries Ashgill et Llandovery, une poussée sénestre de déversement au sud-est qui a placé un fragment de la ceinture de Botwood sur la ceinture des îles Indian. Une déformation progressive postérieure à la série Wenlock du Silurien a produit des failles dextres et des plis droits à l'est de la ligne de Dog Bay, une formation géologique frontière du Silurien, tandis qu'à l'ouest de la ligne, elle a produit des plis se déversant vers le nord-ouest. Un mouvement sénestre de rupture du Silurien supérieur au Dévonien a modifié les lignes Red Indian et GRUB. Des observations structurales et stratigraphiques laissent supposer qu'une obduction de l'Arenig inférieure de la marge de la sous-zone d'Exploits sur la zone de Gander, suivie par une subduction en direction est de l'ancienne croûte océanique (sous-zone de Notre-Dame), le long de la ligne Red Indian, a produit un arc volcanique faisant face à l'ouest. La distension de l'arc vers la fin de la période de l'Arenig a produit un bassin arrière-arc actif. L'inversion structurale et le remplissage rapides du bassin, accompagnés d'une poussée vers l'est, ont débuté au cours de la période de l'Ashgill, probablement par suite de l'arrivée du bouclier laurentien dans la zone de subduction. Les lambeaux d'érosion du bassin arrière-arc ont été bloqués par la subduction en direction ouest au cours des séries Llandovery et Wenlock. Un contact intercontinental, accompagné d'une compression et d'une extrusion ultérieures de fragments en biseau entre des failles synchrones, est survenu pendant le Silurien supérieur.

[Traduit par la rédaction]

\section{INTRODUCTION}

H. Williams (1979) defined the Dunnage Zone of the Appalachian Orogen as relics of the lower Paleozoic Iapetus Ocean. The Dunnage Zone, which played a key role in development of plate tectonic models for ancient rocks (Bird and Dewey, 1971), was first modelled as a product of subduction and obduction of oceanic crust in middle Ordovician time, as deduced on stratigraphic reasoning by $\mathrm{H}$. Williams and Stevens (1974). Such models implicitly assumed that the zone represents a single entity. However, further work showed that the Dunnage Zone consists of several subzones with uncertain relations to one another $(\mathrm{H}$. Williams et al.,
1988; van Berkel and Currie, 1988). Much of its development post-dated obduction (Swinden et al., 1990; Colman-Sadd et al., 1992) with a metamorphic and plutonic climax in Silurian time (Currie et al., 1986; Dunning et al., 1990). New mapping of the type area of the Dunnage Zone around Dunnage Island in northeastern Notre Dame Bay (Fig. 1) suggests a model for the Dunnage Zone which takes into account these complexities.

\section{GEOLOGICAL FRAMEWORK}

A simplified geological map and summary of the stratigraphy and deformation history of the northeastern extrem- 


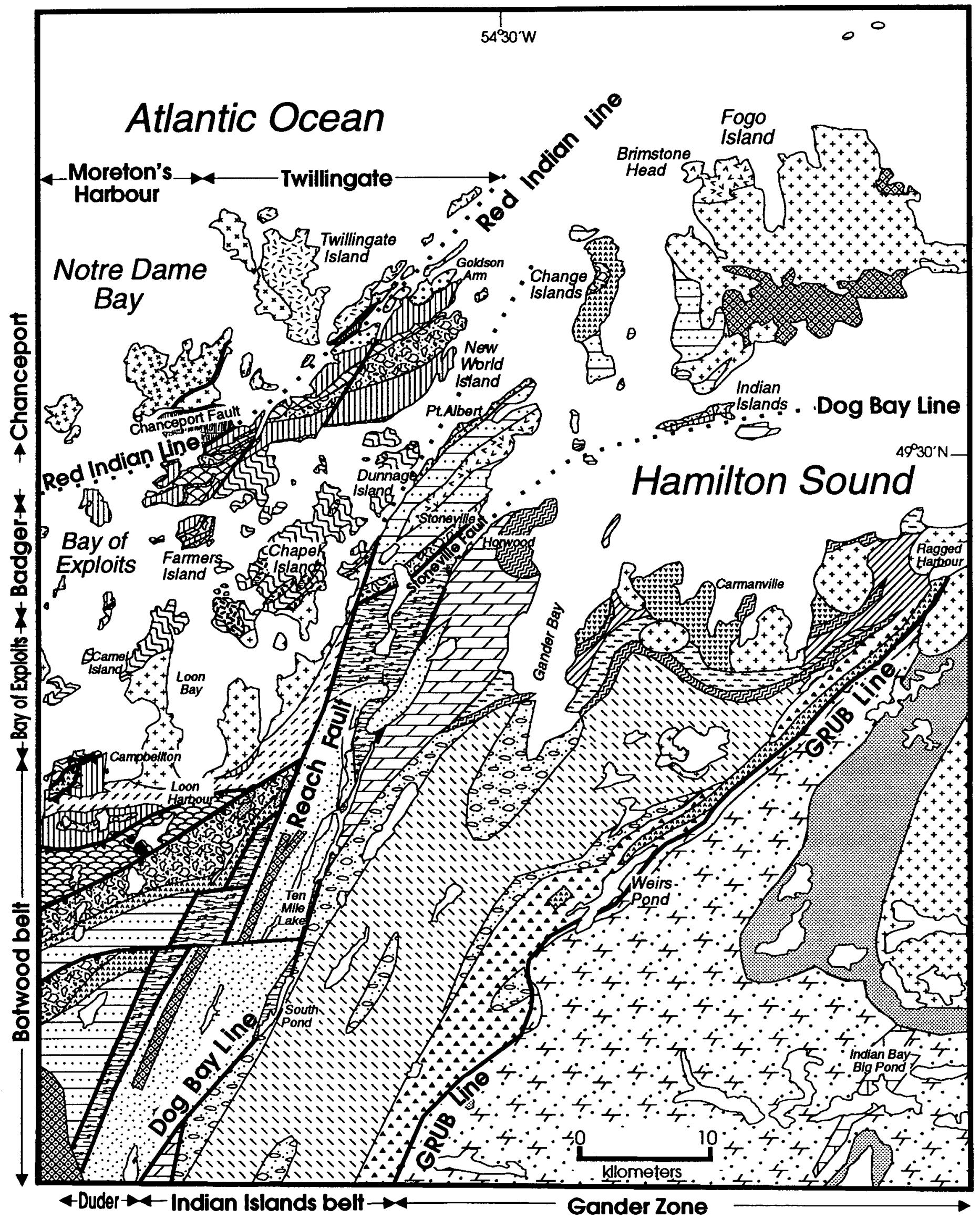

Fig. 1. Simplified geological map of the northeastern extremity of the Dunnage Zone in Newfoundland. See Figure 2 for legend. 


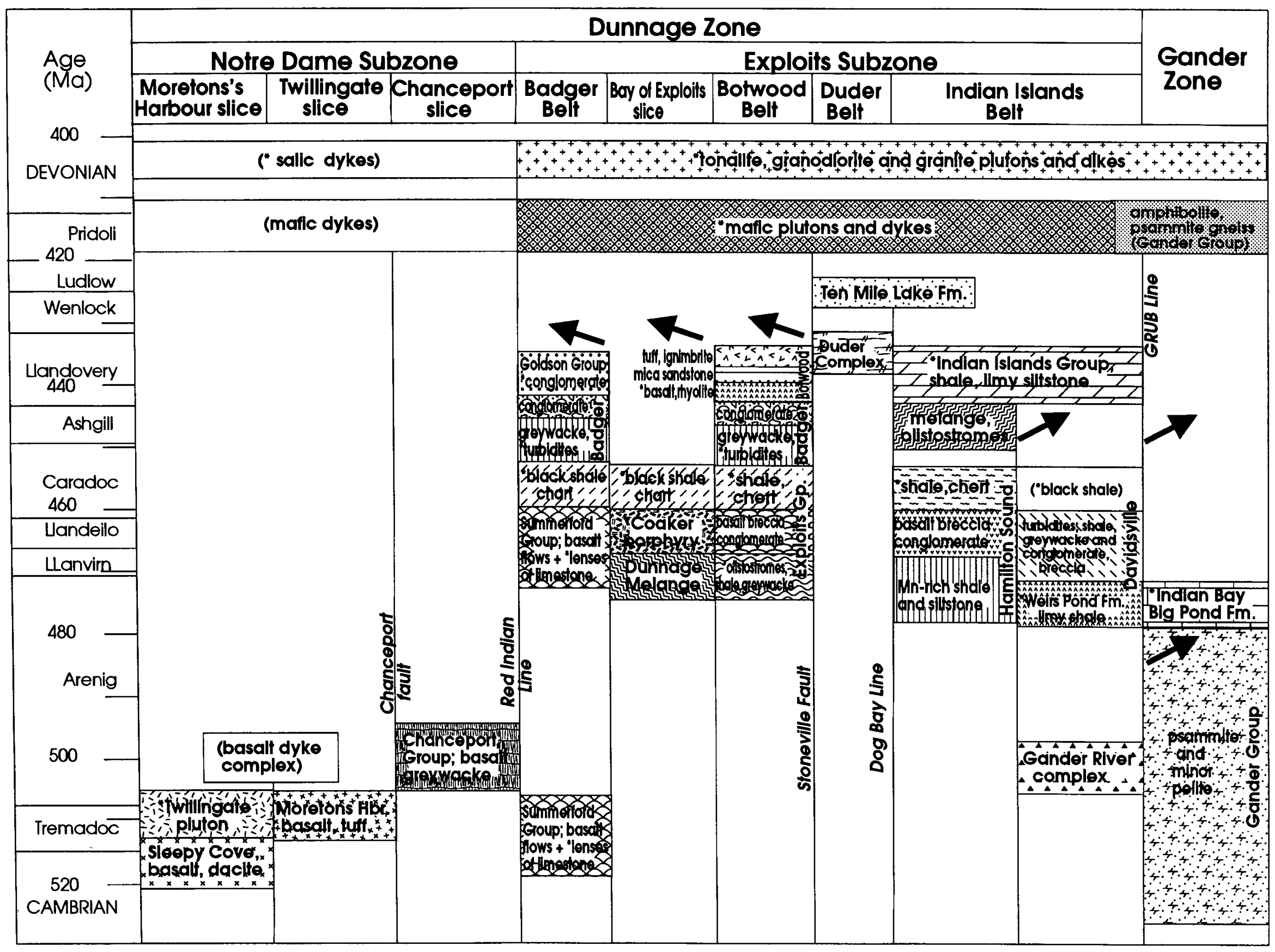

Fig. 2. Structural-stratigraphic chart for the northeastern extremity of the Dunnage Zone in Newfoundland. Except as noted, formally named units are stratigraphic groups. Dated units (fossil or radiometric) are marked with an asterisk. Units in parentheses are not shown on the map. Heavy black arrows indicate timing and direction of tectonic transport of the belt at the base of the arrow over the belt at the arrowhead. The extent of each belt is indicated on Figure 1 . Vertical lines represent faults. Absolute ages are after Tucker et al. (1990). 
ity of the Dunnage Zone are given in Figures 1 and 2. The western parts of this region around New World Island and the Bay of Exploits have been examined by many geologists for more than $\mathbf{5 0}$ years, and there is a large literature recently summarised by Lafrance and Williams (1992). The rocks to the east have been much less studied (see O'Neill, 1991; Currie, 1992, 1993, 1994; Evans et al., 1992 for references).

The region includes parts of two subzones of the Dunnage Zone (Notre Dame and Exploits subzones), as well as the western part of the Gander Zone. These fault-bounded major divisions are in turn dissected by internal faults which bound distinctive stratigraphies. From northwest to southeast the stratigraphy can be summarised as follows.

The Notre Dame Subzone, comprised of lower Ordovician (Arenig) and older volcanic and plutonic rocks of ocean floor and volcanic arc origin (Sleepy Cove, Moretons Harbour and Chanceport groups, Twillingate Pluton), is bounded to the southeast by the Red Indian Line. The Exploits Subzone, between the Red Indian and GRUB lines, consists of five fault-bounded parts. The three western parts (Badger and Botwood belts of H. Williams et al. [1993] plus the Dunnage Melange and associated rocks) are characterised by mid-Ordovician and older volcanic rocks and diverse sedimentary rocks (Exploits and Summerford groups, Dunnage Melange). These parts are tied together by a graptolitic black shale and chert unit, mainly of Caradoc age, conformably overlain in the Badger and Botwood belts by late Ordovician to early Silurian clastic sedimentary rocks (Badger Group). In the Botwood Belt, Silurian volcanic and sedimentary rocks (Botwood Group) overlie the Badger Group. The Reach Fault and the older Stoneville Fault truncate the Botwood Belt to the east. Between the Reach Fault-Stoneville Fault and the Dog Bay Line the Duder Belt consists of tectonic melange (Duder Complex) in which the clasts cannot, in general, be assigned to known stratigraphic units, and unconformably overlying middle to late Silurian red beds (Ten Mile Lake formation). The Indian Islands Belt consists of Silurian limy clastic sedimentary rocks (Indian Islands Group), unconformably overlying middle Ordovician rocks similar to those of the Exploits Group (Hamilton Sound Group), and a mainly turbiditic Ordovician clastic sedimentary sequence (Davidsville Group) resting directly on disrupted ophiolite of the Gander River Complex. The structural base of the Gander River Complex marks the GRUB Line, east of which the Gander Zone comprises middle Cambrian to Arenig clastic rocks (Gander Group) and mafic dykes of uncertain age. All divisions were intruded by late Silurian mafic and felsic dykes, and by granitoid plutons.

\section{DESCRIPTION OF geological SUBdivisions}

\section{Notre Dame Subzone}

Northwest of the Red Indian Line, the Notre Dame Subzone consists of volcanic rocks, volcanogenic sedimentary rocks, mafic dikes and the trondhjemitic Twillingate Pluton. The subzone can be divided into three fault-bounded parts (Fig. 1). Between the Red Indian Line and the Chanceport Fault
(Chanceport slice), the Chanceport Group includes both arc-related calc-alkalic and non-arc tholeiitic volcanic rocks (Dec and Swinden, 1994). On New World Island, pillow basalt, interpillow red chert, silicic volcanic rocks and volcanogenic greywacke predominate (Lafrance and Williams, 1992). The Chanceport Fault merges with the Red Indian Line on eastern New World Island, truncating the Chanceport Group. On the basis of long range correlation, the Chanceport Group is believed to be of Arenig age (Dec and Swinden, 1994). The arc-related Sleepy Cove Group of volcanic rocks, and the Twillingate pluton (507 Ma, Elliot et al., 1991) emplaced within it, form a wedge-shaped region open to the northeast (Twillingate slice). This region is bounded to the southeast by the Chanceport Fault and Red Indian Line (Fig. 1). The southeast margin of the pluton is cut by a vertical, sheeted, mafic dyke complex, suggesting that the original boundary may have been formed by such a complex. To the northwest the Sleepy Cove Group and Twillingate Pluton are separated from the Moretons Harbour slice by a fault diverging from the Chanceport Fault and roughly following the shore of New World Island. A sheeted dike complex dipping gently to the southeast lies on the northwest side of the fault. The Moretons Harbour Group consists of northwest-striking, west-facing pillow lavas, vocaniclastic rocks and an upper (western) unit rich in dacitic rocks. The age of the Moretons Harbour Group is unknown but thought to be Arenig or older. According to Dec and Swinden (1994), the Moretons Harbour Group may have originally underlain the Chanceport Group more or less conformably before development of the (relatively minor) Chanceport Fault.

The diverse assemblages of the Notre Dame Subzone represent oceanic arc and back-arc igneous activity in the Iapetus Ocean in early Arenig and older time. The Red Indian Line and Chanceport Fault are both late, brittle, apparently minor features at their present level of exposure (cf. Dec and Swinden, 1994). If paleomagnetic interpretations attaching major significance to these faults (van der Pluijm et al., 1993) are correct, the present late brittle faults conceal older, much larger, ductile features.

\section{Badger Belt}

The stratigraphy of New World Island has been examined by numerous geologists over the past fifty years without complete consensus (see Lafrance and Williams, 1992 for summary). The elements of the stratigraphy are fairly simple. The oldest rocks (Summerford Group) comprise basaltic volcanics with intercalated limestone lenses, and a thicker, more continuous, limestone or marble unit toward the top. Tremadoc to Llandeilo fossil ages have been reported from the Summerford Group, with the younger ages more abundant. This large range of ages suggests that the group may be composite. Only non-arc chemistry has been documented in the volcanics (Jacobi and Wasowski, 1985). The Summerford Group is conformably overlain by Caradocian black shale and chert, which is in turn conformably overlain by coarsening-upward turbiditic greywacke and conglomerate, formerly termed "Sansom greywacke" and "Goldson 
conglomerate" but grouped by H. Williams et al. (1993) into the Badger Group. Details of nomenclature, deposition and deformation of the Badger Group have given rise to much controversy summarized by Lafrance and Williams (1992). The Silurian Botwood Group, typical of the Exploits Subzone to the southeast, is not present on New World Island. A sequence of conglomerates capped by massive, red boulder conglomerate overlies the Badger Group along Goldson Arm (Goldson Group of Twenhofel and Schrock, 1937). This sequence is clearly distinct from the Badger Group, and may be correlative with parts of the Botwood Group.

\section{Bay of Exploits slice}

The Badger Belt on its southern edge rests against the Dunnage Melange from which it is generally separated by high-angle south-over-north faults, although the contact may locally be stratigraphic (H. Williams, 1994). The Dunnage Melange is separated from the Botwood Belt to the south by a south-over-north fault north of Campbellton (O'Brien, 1993), and by the early Devonian Loon Bay batholith (408 Ma, Elliot et al., 1991) between Campbellton and the Reach Fault. The Dunnage Melange (Hibbard and Williams, 1979; $\mathrm{H}$. Williams, 1994), bedded sections within it, and the Coaker Porphyry which intrudes it (Lorenz, 1984) constitute a fault-bounded lithological assemblage not observed elsewhere in the Exploits Subzone, here referred to as the Bay of Exploits slice. The melange comprises a complex assemblage of tectonised olistostromes, injection or diapiric features, map-scale blocks of volcanic rocks (derived partly from the southwest, partly from the Summerford Group to the north, and partly from unknown sources), and significant thicknesses of coherent bedded siltstone-shale rhythmites, olistostrome beds and conglomerate. Remapping by $\mathrm{H}$. Williams (1994) has emphasized the diversity in lithology and structural style of clasts in the melange, and the unknown provenance of many of them. Bedded sections occur on the northern and southern fringes of the Dunnage Melange $(H$. Williams, 1994). The facings of these sections suggest that they overlie the melange. Melange, bedded sections, cleavage and most small folds are intruded and hornfelsed by the Coaker Porphyry (467 Ma, Elliot et al., 1991), a slightly peraluminous feldspar porphyry which contains abundant small inclusions of serpentinised ultramafic and xenocrystic grospydite garnets (Lorenz, 1984). The porphyry forms a series of small plugs with features suggestive of intrusion into wet mud (H. Williams, 1994). Caradocian black shale and chert stratigraphically overlie the Dunnage Melange on Farmers Island (H. Williams, 1994) providing a stratigraphic link with the rest of the Exploits Subzone.

\section{Botwood Belt}

H. Williams et al. (1993) defined the Botwood Belt to include those regions where the Badger Group is overlain by the Silurian Botwood Group. This definition includes two separated regions, one west of the Reach Fault and south of the Loon Bay batholith, and the other east of the Reach
Fault and north of the batholith extending to Fogo Island. All of the region between the Dog Bay and Reach faults was included by H. Williams et al. (1993) in the Botwood Belt on the grounds that both Badger and Botwood groups, typical of that belt, are exposed northwest of Stoneville. However, the region south of Stoneville exhibits very different stratigraphy dominated by melange and overlying redbeds. The contact between the two stratigraphic packages is marked by a ductile shear zone up to a kilometer wide (Stoneville Fault) which affects the Badger Group and a pelitic unit of the melange. Kinematic indicators demonstrating dextral motion with a slight east-over-west component abound in this zone (H. Williams et al., 1993). From Stoneville northeast to the Indian Islands this shear zone cannot be distinguished from deformation associated with the Dog Bay Line, but southwest of Stoneville the two shear zones diverge with the Stoneville Fault continuing southwest to the Reach Fault, while the Dog Bay Line trends south-southwest. Only the region northwest of the Stoneville Fault is here included in the Botwood Belt.

The portion of the Botwood Belt west of the Reach Fault lies mainly west of the area shown in Figure 1, but occurs in the mapped area as a series of west-vergent thrust slices. This belt has recently been remapped in detail (O'Brien, 1992, 1993; S.H. Williams, 1993; Hughes and O'Brien, 1994) which shows that middle Ordovician strata of the Exploits Group rest, possibly unconformably, on lower Ordovician or older arc-volcanic rocks. The oldest part of this sequence exposed within the area of Figure 1, consists of a single thrust slice of late Arenig psammite, siltstone and pelite with abundant thick olistostromes and debris flows (Hughes and O'Brien, 1994). Overlying Llandeilo-Llanvirn basalt breccia and agglomerate, also occur in a single thrust slice. The chemistry of these rocks closely resembles rocks described by Hughes and O'Brien (1994). Rhyolitic tuff and multicoloured chert conformably overlie the mafic volcanic rocks at Loon Harbour and are in turn overlain by thickbedded black chert with shale interbeds. The multicoloured chert is of Llanvirn age (S.H. Williams, 1993), while the overlying interbedded black shale and chert is of Caradoc age, a characteristic unit found throughout the Exploits Subzone. The chert is in turn conformably overlain by coarsening upward turbiditic greywacke and conglomerate of the late Caradoc to Llandovery Badger Group, the "Sansom-Goldson" association of the older literature. Llandovery terrestrial basalt of the Botwood Group lies on the Badger Group at Port Albert (H. Williams, 1993), where a cleavage in the Badger Group may be truncated by the disconformity. Although volcanic rocks of the lower Botwood Group appear identical on opposite sides of the Reach Fault, the overlying rocks differ. West of the fault they consist entirely of ripple-marked, mudcracked micaceous sandstone and siltstone. East of the fault, the sandstone contains numerous tuff beds, and the upper part contains ignimbrite horizons spectacularly exposed at Brimstone Head on Fogo Island. The Botwood Group is mainly of Llandovery to Wenlock age on the basis of fossils (H. Williams, 1972). 


\section{Duder Belt}

The Duder Belt comprises the region between the Stoneville Fault and the Dog Bay Line. The oldest exposed unit, the Duder Complex (Currie, 1993), comprises three northeast-trending sub-units. The northwestern subunit, up to $2.5 \mathrm{~km}$ wide, consists of intensely cleaved, dark grey shale and siltstone ("paper schist") containing rare inclusions of volcanic rocks and limestone up to a meter across. The block-in-matrix nature of the unit can be seen along the shore below the Pentecostal church in Stoneville. The central subunit comprises spectacular tectonic melange in which blocks of gabbro and mafic volcanics, meters to hundreds of meters across, are enveloped in sheared, homogenised siltstone and shale (Fig. 3). This melange, particularly well exposed on the shore in Horwood, can be traced for more than $50 \mathrm{~km}$, readily recognizable by the mafic igneous blocks which stand up as prominent hillocks. The southeastern sub-unit comprises relatively little strained, east-facing conglomerate, grey or greenish psammite and siltstone-shale rhythmites with olistostrome beds up to a meter thick. These apparently intact rocks contain decameter scale blocks of volcanic rocks (for example $200 \mathrm{~m}$ west of the south end of South Pond) and complexly boudined and fractured mafic dikes. The source(s) of clasts within the melange and olistostromes is unknown. One block of black chert resembles the Exploits Group, and one fossiliferous limestone block resembles similar blocks in Badger Group conglomerate. The volcanic rocks generally resemble the Exploits, Summerford and Hamilton Sound groups. No local source is known for deformed granite debris in the conglomerates (Fig. 4). Although the age of the protoliths of the Duder Complex is unknown, final assembly and deformation of the melange is constrained to early or middle Silurian time, since a block in the melange contains Halysites (T.E. Bolton, personal communication, 1994), and the melange is cut by late Silurian gabbro of the Mount Peyton igneous suite (424 Ma, Dickson, 1994).

The Duder Complex is overlain by red shale, siltstone and sandstone (Ten Mile Lake formation of Currie, 1993). The actual contact has not been seen, but the generally low dips and lack of cleavage in the Ten Mile Lake formation, compared to the steep dips and intense cleavage in the Duder Complex, suggest that it must be a major unconformity. The Ten Mile Lake formation crosses the Dog Bay Line with minor displacement, and conformably overlies Wenlock or younger strata of the Indian Islands Group. Both the Ten Mile Lake formation and the Duder Complex are truncated by the Reach Fault, along which the Ten Mile Lake formation is strongly cleaved. Lithologically the Ten Mile Lake formation differs from the typical "Botwood sandstone" in that sandstone is less prominent, and the sedimentary rocks are never associated with underlying volcanic rocks. The Ten Mile Lake formation predates gabbro of the Mount Peyton igneous suite, which cuts it in the form of large dikes, and hence is probably of middle or late Silurian age.

\section{Indian Islands Belt}

H. Williams et al. (1993) introduced the term Indian Islands Belt for the region between the Dog Bay Line, a Silurian terrane boundary, and the GRUB Line. The stratigraphy of this belt, consists of four major units, namely the Gander River Complex, the Davidsville Group, the Hamilton Sound Group and the Indian Islands Group.

The Gander River Complex, (renamed by O'Neill [1991] from the former Gander River Ultramafic Belt or GRUB), comprises pyroxenite, serpentinite, gabbro, mafic volcanic rocks, trondhjemite and plagioclase porphyry assembled in an intricate series of fault slivers. Fault slivers of diverse sedimentary assemblages are also imbricated with the complex. The complex is generally agreed to represent disnupted ophiolite, but no coherent stratigraphy has yet been reconstructed. The Arenig age of emplacement $(>475 \mathrm{Ma})$ for ophiolitic rocks farther to the southwest (Colman-Sadd et al., 1992) probably also dates original emplacement of the Gander River Complex.

Sedimentary rocks unconformably overlying and imbricated with the Gander River Complex have traditionally been lumped together as the Davidsville Group (Kennedy and McGonigal, 1972). The Davidsville Group includes three diverse, tectonically assembled, parts: (i) a fining-upward turbidite sequence, (ii) limy shale and calcareous sandstone, and (iii) Caradocian black shale. There is little evidence of original close spatial or sedimentological relationships among these components. O'Neill and Blackwood (1989) divided the Davidsville Group into a basal Weirs Pond Formation and overlying turbidites (Hunts Cove and Outflow formations). "Weirs Pond Formation" as defined by O'Neill and Blackwood (1989) included both coarse breccia and conglomerate at the base of the turbidite sequence and the limy assemblage described above. In this paper Weirs Pond Formation is restricted to the limy assemblage.

The transition from Gander River complex to the turbidite sequence is well exposed in roadcuts west of Weirs Pond where a diffuse zone of Gander River Complex several meters wide is broken up into meter-scale blocks with interstices filled with angular clasts. This material grades upward into matrix-supported conglomerate, and then to turbiditic pebble conglomerate and granule sandstone (Currie, 1995) which commonly contains pebbles of serpentinite, chromite grains and blue quartz granules all derived from the Gander River Complex (Fig. 5). These strata contain meter-scale green or purple siltstone-shale rhythmite intercalations, and grade upward into dark grey shale. The maximum thickness of the turbidite sequence is about $1300 \mathrm{~m}$. This sequence contains no materials, such as chert or coticules, related to contemporary volcanism.

Two types of fossiliferous calcareous rocks have been included in the Davidsville Group. Calcareous sandstone with millet-seed quartz grains, containing a late Arenigearly Llanvirn peri-Gondwanan assemblage occurs on Gander Lake (McKerrow and Cocks, 1978), the Trans-Canada 


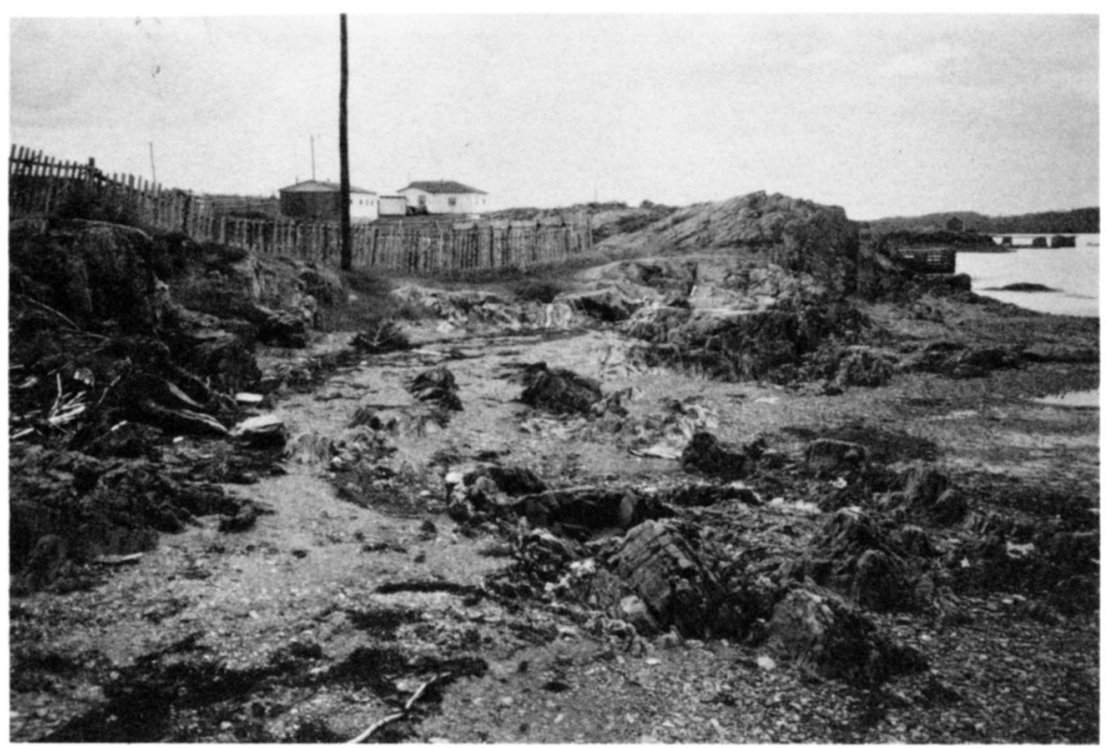

Fig. 3. Gabbro block in sheared mudstone, melange of the Duder Complex, Horwood. The house behind gives the size of the block $(\sim 10 \times 6 \times 3 \mathrm{~m})$.

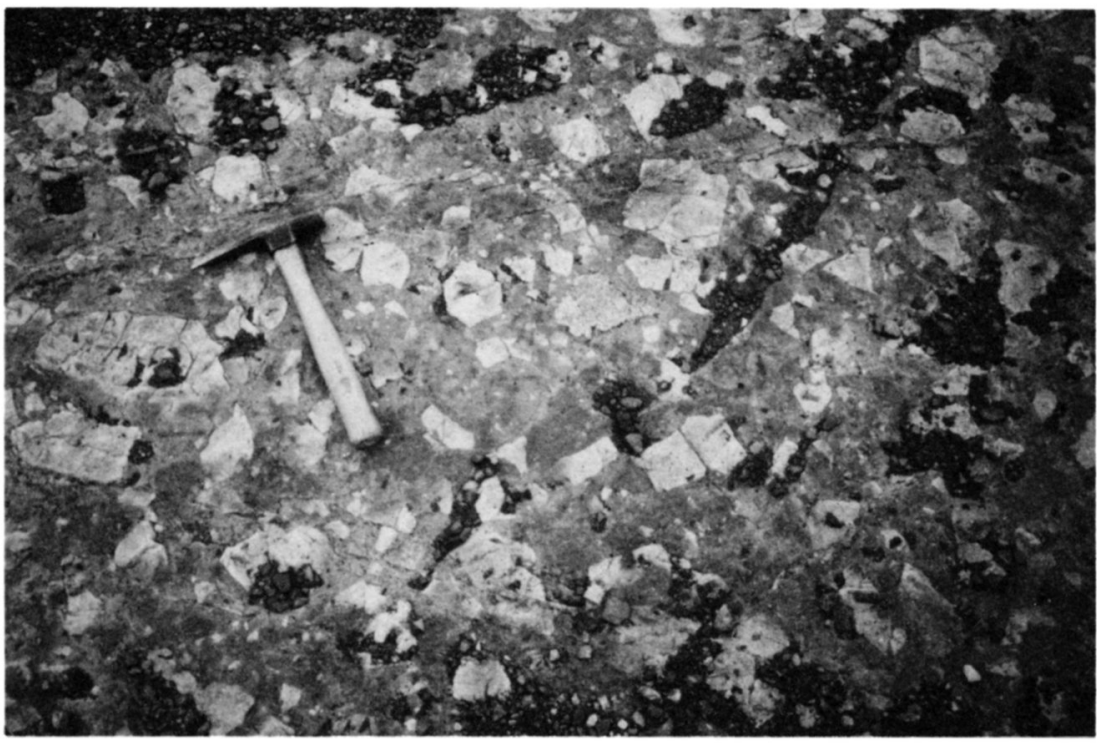

Fig. 4. Conglomerate charged with trondhjemite cobbles, Duder Complex, west of Ten Mile Lake. This fragment, about $200 \mathrm{~m} x 600$ $\mathrm{m}$ in size, preserves an unconformity between a pluton and relatively little-strained sedimentary strata.

Highway (Blackwood, 1982), and south of Weirs Pond. This lithology and assemblage strongly resembles the Indian Bay Big Pond Formation which was assigned by O'Neill (1991) to the Gander Group. On Weirs Pond and to the north, the Gander River Complex is unconformably overlain by fossiliferous calcareous shale with thin limestone bands bearing conodonts of late Arenig to Llandeilo age and Laurentian affinity (Stouge, 1980; Pickerill et al., 1978; Blackwood, 1982). The top of both types of sections are faulted against the structurally overlying Gander River Complex.

A fault-bounded sliver of sheared Caradoc black shale, typical of the Exploits Subzone, occurs on Weirs Pond (O'Neill, 1991), and a similar, unfossiliferous, sliver occurs in a roadcut southwest of Weirs Pond. Neither the Weirs Pond Formation nor Caradocian black shale contact strata of the turbidite sequence. In general, the Weirs Pond Formation is less deformed than the turbidite sequence, and indicates a more stable, shelf-like environment of sedimentation.

The age of the turbidite sequence is uncertain since it is unfossiliferous. However, the base rests unconformably on the Gander River Complex and is probably similar in age to the Weirs Pond Formation (late Arenig-Llandeilo), which also rests unconformably on the Gander River Complex, whereas the dark shales at the top of the turbidite sequence may be related to the Caradocian black shale at Weirs Pond.

The north-northeast-trending Davidsville Group is truncated to the north by the east-northeast-trending Hamilton Sound Group. Along the contact, and dissecting the other units of the group, narrow, sinuous belts of melange con- 


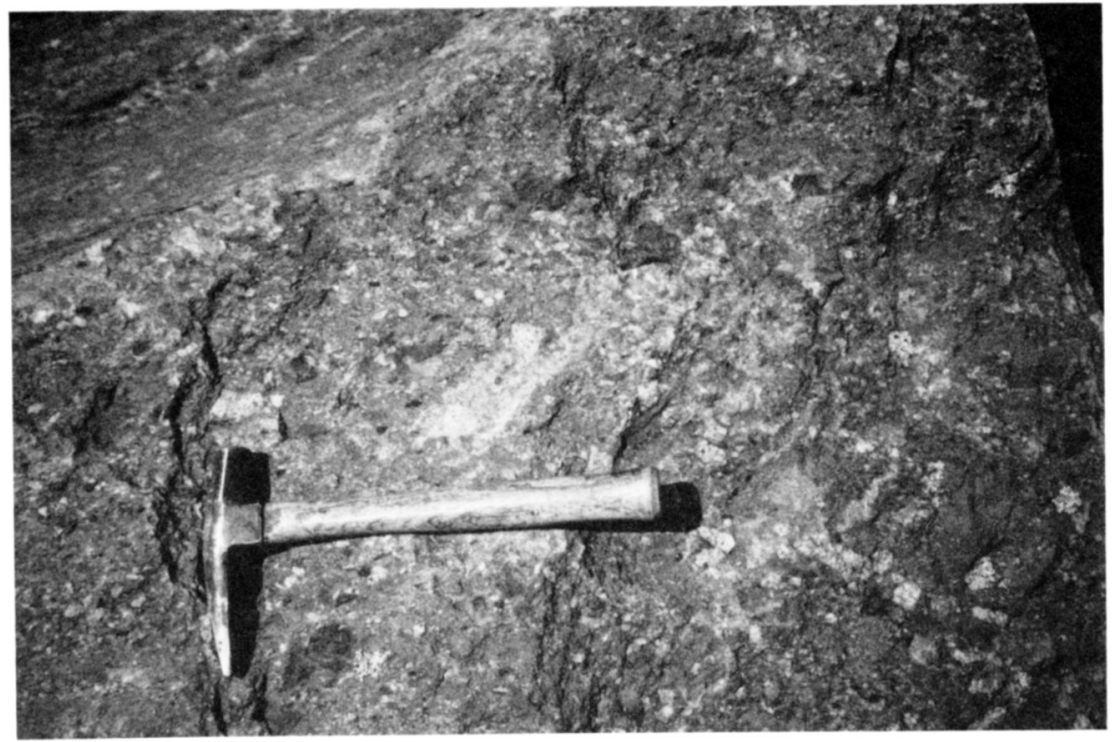

Fig. 5. Sandstone turbidites with conglomerate lenses, Davidsville Group. Road cut west of Weirs Pond.

tain blocks, meters to tens of metres across, floating in a rusty black shale matrix. West of Gander Bay and around Carmanville the large blocks are predominantly of volcanic origin (Fig. 6), but the eastern part of the melange contains large ultramafic knockers, presumably derived from the nearby Gander River Complex. A variety of other sedimentary and igneous clasts, many of them of unknown provenance, also occur in the melange. Melange surrounds an ovoid region of non-arc basalts (Johnston, 1992), mainly coarse volcanic breccia and conglomerate (Fig. 7) which formed on the southern slope and apron of a volcano. Caradocian black graptolitic shale and bedded manganiferous chert fringe the volcanic rocks on the south side. This sulphide-rich black shale provided much of the material for the melange matrix. The volcanic chert-black shale sequence strongly resembles in lithology and age the Exploits Group to the west. Most islands in Hamilton Sound are underlain by thinly laminated, turbiditic, coticule-bearing rhythmites which contain numerous olistostrome beds up to $1 \mathrm{~m}$ thick. These strata somewhat resemble bedded sections found within the Dunnage Melange to the west, for example on Chapel and Camel Islands (H. Williams, 1994). Small areas of other sedimentary units of unknown age and affinity occur in the Hamilton Sound Group on islands at the mouth of Gander Bay. The correct stratigraphic ordering of units of the Hamilton Sound Group cannot be determined from outcrop observations due to inadequate outcrop and structural complexity, but comparison with contemporary, lithologically similar units in the Botwood Belt suggests that the coticule-bearing siltstone is the oldest, and the graptolitic shale and chert the youngest unit. If this is correct, then the observed apparent order has been structurally reversed.

No contacts between the Hamilton Sound and Davidsville groups have been found, but rocks close to the contact are intensely sheared along steeply dipping planes, and within a kilometer of the contact the Davidsville Group exhibits downward-facing folds (Karlstrom et al., 1982). Karlstrom et al. (1982) suggested that the Hamilton Sound Group shared a structural history with rocks west of the Dog Bay Line.

The Llandovery and younger Indian Islands Group unconformably overlies the Hamilton Sound Group. Two exposures of the contact on the west side of Gander Bay exhibit only a small divergence in attitude (H. Williams, 1993), but on a regional scale the Indian Islands Group truncates the trend of the Hamilton Sound Group at about a $45^{\circ}$ angle. Small east-over-west high angle faults everywhere obscure the Indian Islands-Davidsville contact. However, structural relations between the Hamilton Sound and Davidsville groups imply that the Indian Islands-Davidsville contact must also be an unconformity or major fault. The Indian Islands Group consists of discontinuous basal limestone and limy shale, locally reduced to a breccia of large slabs of Halysites-bearing limestone, conformably overlain by monotonous calcareous siltstone with limestone lenticles, from which a Wenlock brachipod has been recovered (Wu, 1978). The siltstone is in turn overlain by grey shale with thin buff siltstone beds. South of Horwood the Indian Islands Group is conformably overlain by red shale and siltstone of the Ten Mile Lake formation (Currie, 1993).

\section{Gander Zone}

The Gander Zone comprises the Gander Group, its metamorphosed, migmatised and diked equivalents, and various Siluro-Devonian intrusive rocks. The Gander Group consists mainly of monotonous feldspathic psammites with rare pebbly beds derived from a continental source thought to be part of Gondwana on the basis of detrital U-Pb zircon ages of 510 to $650 \mathrm{Ma}$ (O'Neill, 1991). The youngest part of the Gander Group, according to O'Neill (1991), is calcareous psammite of the Indian Bay Big Pond Formation, which contains a late Arenig Celtic fauna (Wonderly and Neuman, 1984). Van Staal and Williams (1991) noted that the Indian Bay Big Pond Formation strongly resembles rocks of the Exploits Subzone, and suggested that part of the Exploits Subzone 


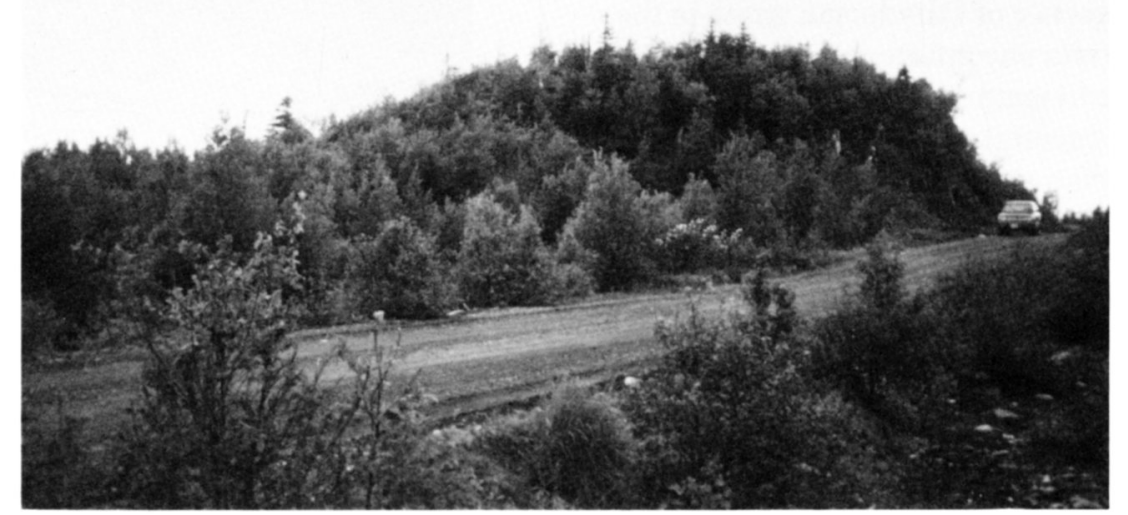

Fig. 6. Large volcanic block in melange, Hamilton Sound Group west of Gander Bay. The size of the block ( $\sim 50 \mathrm{~m}$ in diameter by 10 $\mathrm{m}$ high) can be gauged from the roadway and truck.

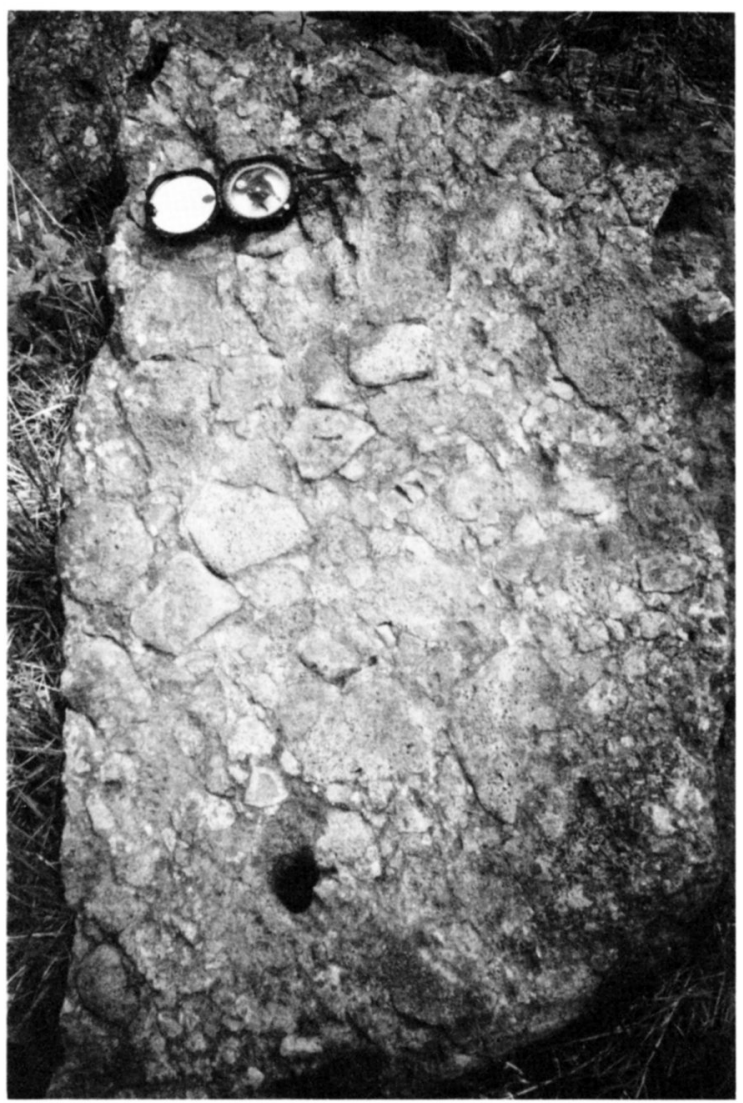

Fig. 7. Basalt breccia or conglomerate, Hamilton Sound Group at Carmanville. This lithology is identical to much of the volcanics of the Exploits Group at Loon Harbour.

originally conformably overlay the Gander Zone as an overlap assemblage. The structural top of the Gander Group along the GRUB Line contains a large proportion of black pelite (Currie, 1992) which locally contains coticules. The same region contains a high proportion of iron-rich tholeiitic mafic dykes, locally forming up to $10 \%$ of the outcrop, now largely boudined and converted to schistose or gneissic amphibolites. This association of coticule-bearing rocks and tholeiitic dykes resembles that described by van Staal et al. (1994) along the northwest margin of the Gander Zone in southwestern Newfoundland.

\section{Structure of the Dunnage Zone}

P.F. Williams and co-workers (Karlstrom et al., 1982; Elliot et al., 1991; Lafrance and Williams, 1992) showed that similar structural elements of late Ordovician and Silurian age can be recognized across the whole of the Dunnage Zone. These workers did not recognize middle Ordovician or older structural elements, but Colman-Sadd et al. (1992) showed that the eastern margin of the Exploits Subzone was obducted onto the Gander Zone in early Arenig time ( $>475$ Ma). This event is here termed $D_{1}$. East-vergent recumbent folds characteristic of the Gander Group (Hanmer, 1981) may be of this age, but Piasecki (1992) noted four periods of deformation along the GRUB Line, the youngest of which affects the late Silurian Ragged Harbour pluton. The Coaker Porphyry (467 Ma, Elliot et al., 1991) truncates a strong cleavage and numerous folds of cleavage in the Dunnage Melange. Since the Dunnage Melange includes within it fragments of late Arenig strata of the Exploits Group (Hibbard and Williams, 1979; Hughes and O'Brien, 1994), emplacement and initial deformation of the melange are restricted to late Arenig to Llanvirn time. This event is here termed $D_{2}$. No deformation of this age was noted by Lafrance and Williams (1992) in the Tremadoc to Llanvirn Summerford Group of New World Island.

Lafrance and Williams (1992) recognized three periods of deformation. The oldest (here termed $\mathrm{D}_{3}$ ), deduced to be a pervasive thrusting to the southeast, was assigned a Llandovery or younger age, since small scale thrust ramps and flats of this deformation are common in the Badger Group which 
locally contains blocks with Llandovery fossils. However, O'Brien (1993) has shown that much of the Badger Group is of Ashgill age. $D_{3}$ could have begun in Ashgill time but persisted locally into Llandovery time. Southeast of the Dog Bay Line, emplacement of the Hamilton Sound Group over the Davidsville Group is constrained to post-Caradoc and pre-Llandovery time by presence of Caradocian strata in the melange and Llandovery strata unconformably overlying the melange. Imbrication of sedimentary strata into the Gander River Complex is likewise constrained to post-Caradoc time by the presence of Caradocian strata within the imbricates, and to easterly vergence by ramps and flats within the Gander River Complex. Both of these large-scale events have the timing and kinematics of $D_{3}$.

Lafrance and Williams (1992) described their second deformation $\left(D_{4}\right)$ as a progressive event characterised by ductile dextral shear and formation of large, gently-plunging folds, and deduced it to be of late Silurian age. West of the Dog Bay Line, folds are moderately overturned toward the west (H. Williams, 1993). East of the Dog Bay Line, the oldest deformation of the Indian Islands Group which produced close, upright, gently-plunging folding (Fig. 8), must be of similar age, since it affects Wenlock and younger strata. Geometrically similar, kilometer-scale, gently-plunging folds occur in the Davidsville Group. An element of east-over-west tectonic transport is suggested by west-vergent folds west of the Dog Bay Line. This deformation appears east of the Dog Bay Line as small-scale, high-angle reverse faults. Smallscale, steeply-plunging dextrally assymetric folds, as well as narrow $(<5 \mathrm{~m})$ dextral mylonites and numerous dextral kinematic indicators occur in a broad zone extending from the Stoneville Fault to several kilometers east of the Dog Bay Line.

Lafrance and Williams (1992) distinguished a late period of deformation characterised by sinistral rectilinear brittle faults, such as the Reach Fault, and late sinistral displacement on the Red Indian Line. On the grounds that one of these faults displaced a Jurassic? lamprophyre dike, Lafrance and Williams (1992) tentatively suggested that displacment was of Mesozoic age. However, the Reach Fault and associated parallel faults are cut by the Mount Peyton igneous suite of late Silurian age. Earliest fault movements therefore predated late Silurian time, but movement locally continued at least through early Devonian time, since the Reach Fault truncates the early Devonian (408 Ma) Loon Bay batholith.

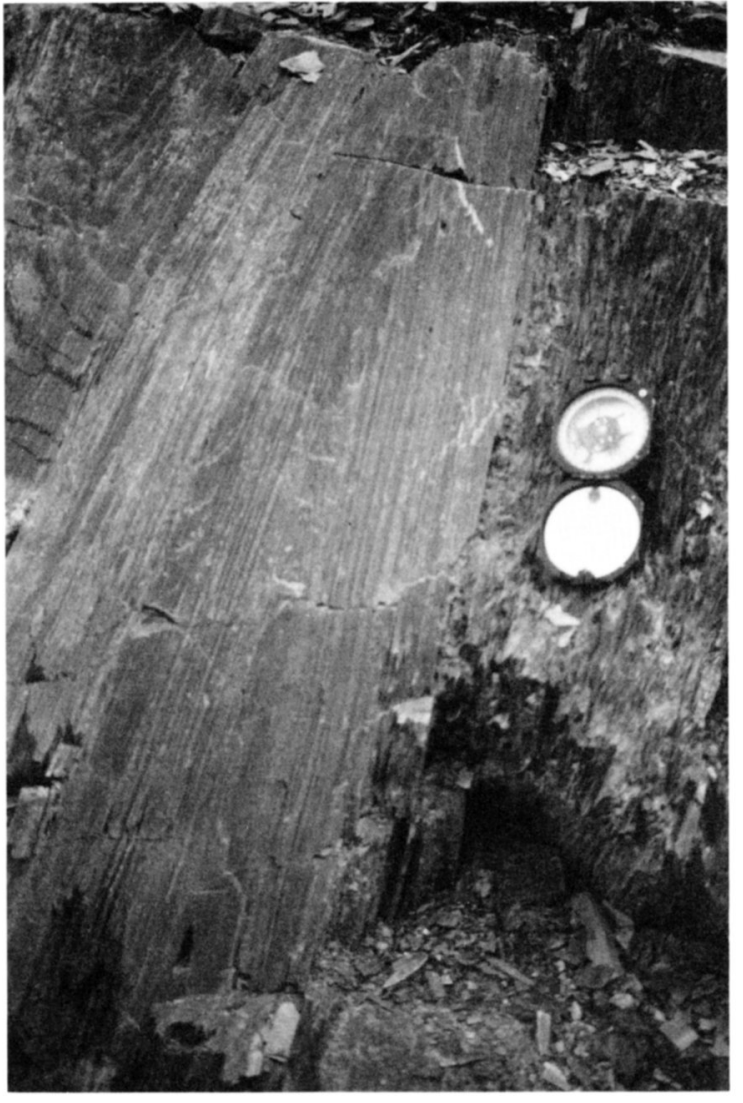

Fig. 8. Upright folds, Horwood Formation, road-cut south of Horwood. Folds of identical style but much larger size occur in the Davidsville Group.

Mesozoic movement deduced by Lafrance and Williams (1992) involved reactivation of older faults.

\section{TECTONIC INTERPRETATION}

The tectonic interpretation favoured by this work is cartooned in Figure 9, and discussed below. The work of Colman-Sadd et al. (1992) implied obduction of the eastern edge of the Dunnage Zone, and by implication of the Gander River Complex, onto the Gander Zone in late Arenig or older time ( $>475 \mathrm{Ma}$, Fig. 9a). East-vergent recumbent folds in the Gander Group may record this event, but if so the structures have been modified by younger events. The pres-

Fig. 9. Cartoon of development of the northeast extremity of the Dunnage Zone in Newfoundland. Patterns for supracrustal units are the same as in Figure 1. (A) Arenig; Obduction of ophiolite (Gander River Complex) onto the Gander Group. (B) Late Arenig; Formation of a west-facing volcanic arc. Various facies of the Davidsville Group form on the continental margin behind the arc. (C) Llanvirn-Caradoc; The volcanic arc is rifted with formation of a back-arc basin due to roll-back of the descending slab. Mantle upwelling and igneous activity in the basin may be intensified by break-off and sinking of the old descending slab. The Dunnage Melange may have formed before arc-rifting, but the Summerford (most of) and Exploits groups form in the back-arc basin. The Caradoc black shale-chert horizon is assumed to mark the end of back-arc basin igneous activity. (D) Ashgill-Llandovery; Rapid deposition of westerly-derived clastics (Badger Group) accompanied by eastward-thrusting (emplacement of the Hamilton Sound Group, imbrication of the Gander River Complex). This activity probably resulted from arrival of Laurentia at the subduction zone. (E) Llandovery-Wenlock; Floor of the former back-arc basin is consumed by westward, dextral subduction. Botwood Group forms on the hanging wall above a mantle upwelling, the Indian Islands Group forms on the passive descending margin, and the Duder Complex represents an accretionary complex. (F) Pridoli-Ludlow; Final compression of the Dunnage Zone with formation of lateral escape structures between steep, late, brittle sinistral and dextral faults. The Ten Mile Lake formation forms in local basins caused by such structures between the Reach Fault and Dog Bay Line. 
A

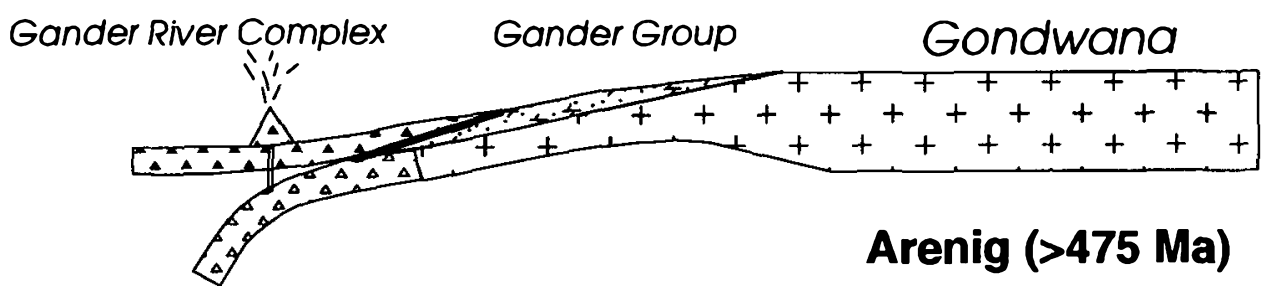

B
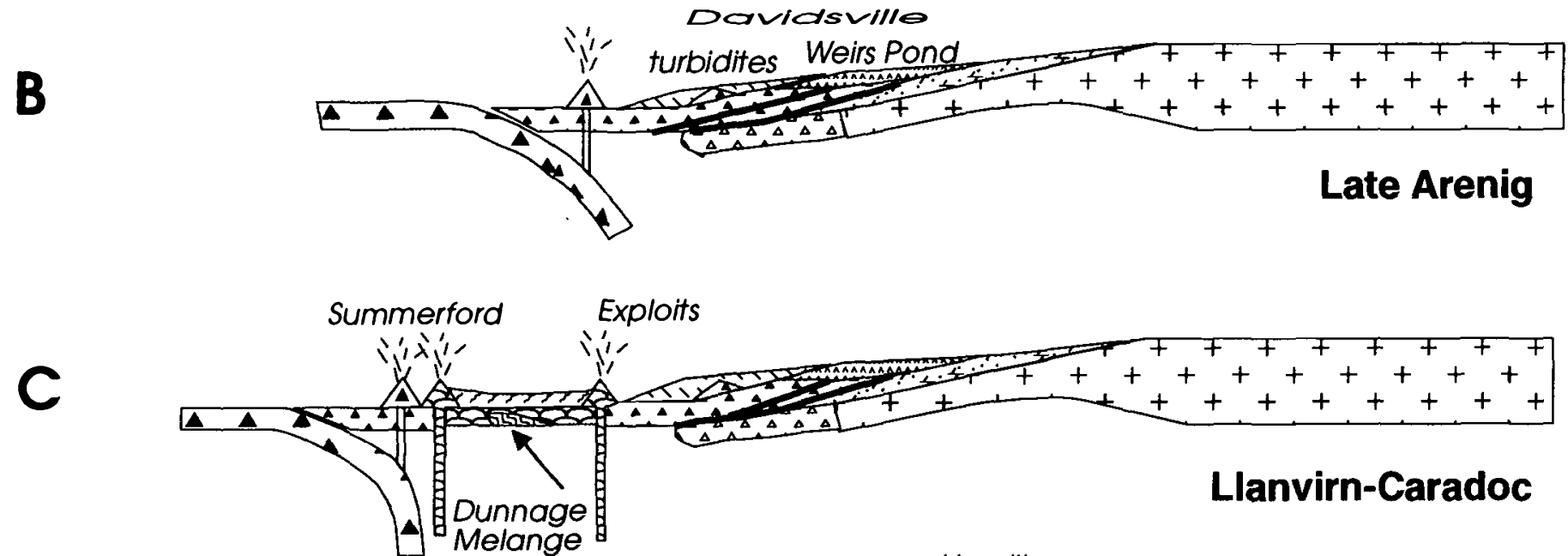

Laurentia

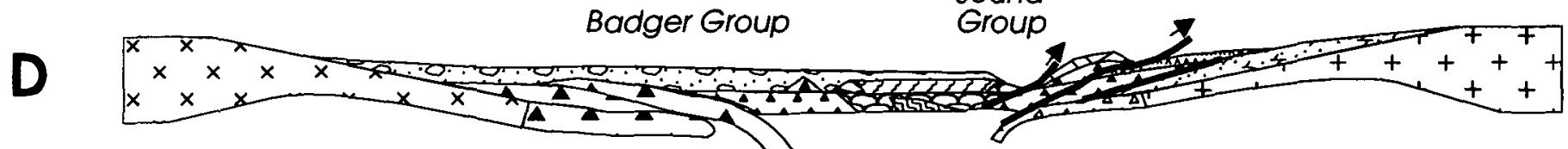

Ashgill-Llandovery
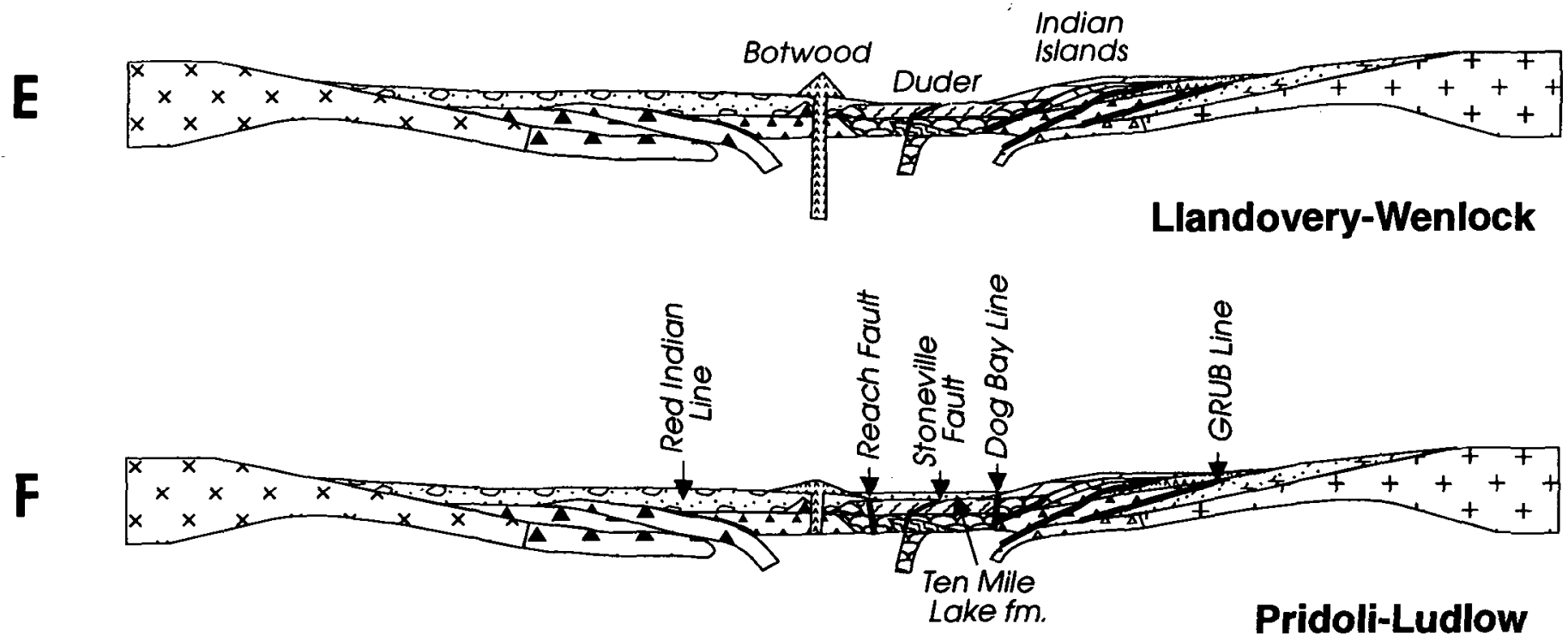
ence of arc-type volcanics of Arenig age in the Exploits Subzone (Swinden et al., 1990; O'Brien, 1993), together with the composite oceanic assemblages of the Notre Dame Subzone, suggest, but do not prove, subsequent southeast-dipping subduction near the Red Indian Line (Fig. 9b) as hypothesized by $\mathrm{H}$. Williams et al. (1988), although Dec and Swinden (1994) cast some doubt on this model. Such subduction would consume early Arenig and older oceanic crust to the northwest and build a west-facing volcanic arc. Transition from arc-type to non-arc volcanics in the Exploits Zone has been documented by Swinden et al. (1990) and dated by O'Brien and coworkers (O'Brien, 1993; Hughes and O'Brien, 1994) as late Arenig or Llanvirn. This transition suggests opening of a back-arc basin (Fig. 9c). The model implies that the Summerford Group, from which fossils as old as Tremadoc have been recovered, must contain within it the transition from arc-type to non-arc volcanics. Residual uncertainties in the age of formation of the Dunnage Melange permit three models for origin. (i) The melange could be older than middle Arenig, formed during west-dipping subduction, and now exposed in a tectonic window. If late Arenig blocks of the Exploits Group occur in the melange (Hibbard and Williams, 1979) this scenario is unlikely. (ii) The melange could be of late Arenig age, associated with east-dipping subduction. On this hypothesis, opening of the back-arc basin and subsequent migration of the volcanic arc over its accretionary wedge complex could both be ascribed to slab roll-back due to subduction of relatively old, dense sea-floor of the Notre Dame Subzone. (iii) Melange could be ascribed to major olistostromes set off by opening of the back-arc basin. This possibility does not explain the common presence of metamorphic rocks in the melange, or pre-Llanvirn lithification shown by strong cleavage cut by the Coaker Porphyry. Igneous activity in the back-arc basin lasted from late Arenig time to mid-Caradoc time when the whole of the Exploits Subzone was blanketed by black shale and chert, requiring a starved basin with little clastic precipitation. Assuming reasonable spreading rates of 2 to $10 \mathrm{~cm}$ per year, this period of about $15 \mathrm{Ma}$ (Tucker et al., 1990) would allow formation of a basin 300 to $1500 \mathrm{~km}$ wide. During backarc basin development contemporary strata of the Davidsville Group and Indian Bay Big Pond Formation were deposited east of the back-arc basin on a passive margin of Gondwana. The Indian Bay Big Pond Formation lies conformably on the Gander Group (O'Neill, 1991), whereas the Davidsville Group lies unconformably on the Gander River Complex. Collectively the sedimentary rocks range from relatively shallow-water, stable-shelf sediments to deeper-water turbidites, suggesting that this passive margin was extensive.

In Ashgill to early Llandovery time rapid clastic, westerly-derived, coarsening-upward sedimentation (Badger Group), and pervasive northwest-over-southeast thrusting (imbrication of Davidsville Group and Gander River Complex, emplacement of the Hamilton Sound Group) indicate uplift and shortening of the Exploits Subzone. Studies by Piasecki (1992) along the GRUB Line suggest that this east-vergent thrusting had a strong sinistral component. These data indicate a new tectonic regime. Figure $9 d$ assumes compression and uplift resulted from arrival of Laurentia or some large fragment of it at the subduction zone.

The present width of remnants of the back-arc basin (Exploits and Summerford groups, Dunnage Melange) does not excede a few tens of kilometers, whereas the estimated original width of the basin was many tens or hundreds of kilometers. The strong contrast between the Llandovery Botwood and Indian Islands groups implies that they must have been deposited a considerable distance apart, although outcrops of the contrasting groups are now found within a kilometer of each other. Loss of so much, mainly oceanic, basin floor suggests subduction in Llandovery and younger time (Fig. 9e). According to this model, the floor of the back-arc basin east of the Stoneville Fault was consumed by westward subduction except for fragmentary relics preserved in the Duder Complex, an accretionary wedge complex containing relics of the vanished floor, and the allochthonous Hamilton Sound Group which was emplaced before subduction began. The Indian Islands Group formed on the relatively stable southeast passive margin, and the Botwood Group on the west margin, higher-standing and with more igneous activity, due to mantle upwelling. The model assumes convergence with dextral assymetry to explain $D_{2}$ structures, and final overriding of the west side by the east to explain west-verging structures west of the Stoneville Fault. These structures folded Wenlock strata but are cut by the late Silurian Mount Peyton igneous suite.

The Ten Mile Lake formation can be assigned to a brief period of middle to late Silurian time between final closure of the back-arc basin, with continent-continent contact, and climactic late Silurian metamorphism and plutonism. This period was marked by continuing northwest-southeast compression of increasingly brittle style, with development of planar, brittle faults such as the Reach Fault and related north-northeast and east-northeast trending faults. Some of these faults were reactivated during Mesozoic opening of the modern Atlantic Ocean.

The model proposed for the northeastern end of the Dunnage Zone resembles the model proposed by van Staal (1987) for the Dunnage Zone of New Brunswick in the presence of a Llanvirn-Llandeilo back-arc basin, closed in Caradoc or later time, and the reversal in sense of transcurrent motion between mid-Ordovician and late Silurian. At present, it is uncertain whether these regions represent separated parts of a once continuous large basin, or form remnants of separate smaller basins which responded similarly to orogenwide forces.

\section{ACKNowledgements}

The mapping reported here was a joint project of Hank Williams, Memorial University, Mark Piasecki, University of Keele, and myself. I have also been greatly assisted by field visits from Brien O'Brien, Dave Evans and Steve Colman-Sadd of the Geological Surveys Branch, Newfoundland Department of Mines and Energy. I wish to record my ap- 
preciation of stimulating discussions with Cees van Staal. None of these gentlemen are responsible for the speculative ideas expressed in this paper. This paper is Geological Survey of Canada contribution 14595.

BIRD, J.M. and DEWEY, J.F. 1971. Lithosphere plate-continental margin tectonics and the evolution of the Appalachian orogen. Geological Society of America Bulletin, 81, pp. 1031-1060.

BLACKWOOD, R.F. 1982. Geology of the Gander Lake (2D/15) and Gander River (2E/2) area. Newfoundland Department of Mines and Energy, Mineral Development Division, Report 82-4, 56 p.

BoycE, W.D. and Ash, J.S. 1994. New Silurian-Devonian(?) faunas from the Gander (NTS 2D/15) and Botwood (2E/3) map areas. Newfoundland Department of Mines and Energy, Geological Surveys Branch, Report 94-1, pp. 53-64.

Colman-SAdD, S.P., Dunning, G.R., and Dec, T. 1992. Dunnage-Gander relationships and Ordovician orogeny in central Newfoundland; a sediment provenance and $\mathrm{U} / \mathrm{Pb}$ age study. American Journal of Science, 292, pp. 317-355.

CURRIE, K.L. 1992. A new look at Gander-Dunnage relations in Carmanville map-area, Newfoundland. Geological Survey of Canada, Paper 92-1D, pp. 27-33.

- 1993. Ordovician-Silurian stratigraphy between Gander Bay and Birchy Bay, Newfoundland. Geological Survey of Canada, Paper 93-1D, pp. 11-18.

1994. Reconsidering parts of Comfort Cove and Gander River map-areas, Dunnage Zone of Newfoundland. Geological Survey of Canada, Current Research 1994-D, pp. 33-40.

- 1995. A tale of shale - stratigraphic problems in the Gander River map-area, Newfoundland. Geological Survey of Canada, Current Research 1995-D, pp. 73-80

Currie, K.L., Chandler, F.W., and Whalen, J.B. 1986. A Silurian magmatic event in Atlantic Canada and its implications for Applachian tectonics. Geological Association of Canada, Program with Abstracts, 11, p. 61 .

Dec, T. and Swinden, H.S. 1994. Lithostratigraphic model, geochemistry and sedimentology of the Cottrells Cove Group, BuchansRoberts Arm Volcanic Belt, Notre Dame Subzone. Newfoundland Department of Mines and Energy, Geological Surveys Branch, Report 94-1, pp. 77-100.

Dickson, W.L. 1994. Geology of the southern portion of the Botwood map-area (NTS 2E/3), north-central Newfoundland. Newfoundland Department of Mines and Energy, Geological Surveys Branch, Report 94-1, pp. 101-116.

Dunning, G.R., O'Brien, S.J., Colman-Sadd, S.P., Blackwood, R.F., Dickson, L.W., O'NeILL, P.P., and KROGH, T.E. 1990. Silurian orogeny in the Newfoundland Appalachians. Journal of Geology, 98, pp. 859-913.

Elliot, C.G., DunNing, G.R., and Williams, P.F. 1991. New U-Pb zircon age constraints on the timing of deformation in north-central Newfoundland and implications for early Paleozoic Appalachian orogenesis. Geological Society of America Bulletin, 103, pp. 125-135.

Evans, D.T.W., Hayes, J.P., and Blackwood, R.F. 1992. Gander River, Newfoundland. Newfoundland Department of Mines and Energy, Geological Surveys Branch, Map 92-21.

HANMER, S. 1981. Tectonic significance of the northeastern Gander Zone, Newfoundland: an Acadian ductile shear zone. Canadian Journal of Earth Sciences, 18, pp. 121-135.

Hibbard, J. 1983. Geology of the Baie Verte Peninsula, Newfoundland. Newfoundland Department of Mines and Energy, Mineral Development Division, Memoir 2, $279 \mathrm{p}$.

HibBaRd, J.P. and Williams, H. 1979. The regional setting of the Dunnage Melange in the Newfoundland Appalachians. American Jour- nal of Science, 279, pp. 993-1021.

Hughes, R.J. and O'Brien, B.H. 1994. Syndepositional transport on a deep marine slope and soft sediment reworking of detritus from an exhumed Iapetan arc: evidence from the upper New Bay Formation of the Exploits Group. Newfoundland Department of Mines and Energy, Geological Surveys Branch, Report 94-1, pp. 135-146.

JACOBI, R.D. and WASOWSKI, J.J. 1985. Geochemistry and plate-tectonic significance of the volcanic rocks of the Summerford Group, north-central Newfoundland. Geology, 13, pp. 126-130.

Johnston, D. 1992. The Noggin Cove Formation, Carmanville area, northeastern Newfoundland; a back-arc volcanic complex. Geological Survey of Canada, Paper 92-1E, pp. 27-36.

Karlstrom, K.E., van Der Pluis, B.A., and Williams, P.F. 1982. Structural interpretation of the eastern Notre Dame Bay area, Newfoundland. Regional post-Middle Silurian thrusting and asymmetrical folding. Canadian Journal of Earth Sciences, 19, pp. 2325-2341.

KenNedy, M.J. and MCGonigal, M.H. 1972. The Gander Lake and Davidsville Groups of northeastern Newfoundland: new data and geotectonic implications. Canadian Journal of Earth Sciences 9 , pp. $452-459$.

Lafrance, B. and Williams, P.F. 1992. Silurian deformation in eastern Notre Dame Bay, Newfoundland. Canadian Joumal of Earth Sciences, 29, pp. 1899-1914.

LORENZ, B.E. 1984. A study of the intrusive rocks of the Dunnage Melange, Newfoundland. Ph.D. thesis, Memorial University of Newfoundland, Saint John's, Newfoundland, 220 p.

McKerrow, W.S. and Cocks, L.R.M. 1978. A lower Paleozoic trench-fill sequence, New World Island, Newfoundland. Geological Society of America Bulletin, 89, pp. 1121-1132.

O'BRIEN, B.H. 1992 Geology of the region around Lewisporte (parts of 2E/2,3,6,7), north-central Newfoundland. Newfoundland Department of Mines and Energy, Geological Surveys Branch, Open File Map 92-25.

- 1993. A mappers guide to Notre Dame Bay's folded thrust faults: evolution and regional. Newfoundland Department of Mines and Energy, Geological Surveys Branch, Report 93-1, pp. 279-291.

O'NeILL, P.P. 1991. Geology of the Weirs Pond area, Newfoundland (NTS 2E/1). Newfoundland Department of Mines and Energy, Geological Surveys Branch, Report 91-3, 144 p.

O'NEILL, P.P. and BLACKWOOD, R.F. 1989. A proposal for revised stratigraphic nomenclature of the Gander and Davidsville groups and the Gander River ultrabasic belt of northeastern Newfoundland. Newfoundland Department of Mines and Energy, Mineral Development Division, Report 89-1, pp. 127-130.

PIASECKI, M.A.J. 1992. Tectonics across the Gander-Dunnage boundary in northeastern Newfoundland. Geological Survey of Canada, Paper 92-1E, pp. 259-268.

Pickerill, R.K., Pajari, G.E., Currie, K.L., and Berger, A.R. 1978. Carmanville map-area, Newfoundland; the northeastern end of the Appalachians. Geological Survey of Canada, Paper 78-1A, pp. 209-216.

Stouge, S. 1980. Conodonts from the Davidsville Group, northeastern Newfoundland. Canadian Journal of Earth Sciences, 17, pp. 268-272.

Swinden, H.S., Jenner, G.A., Fryer, B.J., Hertogen, J., and Roddick, J.C. 1990. Petrogenesis and paleo-tectonic history of the Wild Bight Group, an Ordovician rifted island arc in central Newfoundland. Contributions to Mineralogy and Petrology, 105, pp. 219-241.

TUCKER, R.D., Krogh, T.E., Ross, R.J., and Williams, S.H. 1990. Time-scale calibration by high-precision U-Pb zircon dating of interstratified volcanic ashes in the Ordovician and Lower Silurian types of Britain. Earth and Planetary Science Letters, 100, pp. 51-58. 
TWENhofEL, W.H. and Schrock, R.R. 1937. Silurian strata of Notre Dame Bay and Exploits Valley, Newfoundland. Geological Society of America Bulletin, 48, pp. 1743-1772.

van Berkel, J.T and Currie, K.L. 1988: Geology of the Puddle Pond (12A/5) and Little Grand Lake (12A/12) map areas, southwestern Newfoundland. Newfoundland Department of Mines and Energy, Mineral Development Division, Report 88-1, pp. 99-107.

VAN Der Pluijm, B.A., Johnson, R.J.E., and VAN Der Voo, R. 1993. Paleogeography, accretionary history and tectonic scenario: a working hypothesis for the Ordovician and Silurian evolution of the northern Appalachians. Geological Society of America, Special Paper 275, pp. 27-40.

van StaAl, C.R. 1987. Tectonic setting of the Tetagouche Group in northern New Brunswick implications for plate tectonic models of the Northern Appalachians. Canadian Journal of Earth Sciences, 24, pp. 1329-1351.

van StaAl, C.R. and Williams, H. 1991. Dunnage Zone-Gander Zone relationships in the Canadian Appalachians. Geological Society of America, Abstracts with Program, 23, p. 143.

van Staal, C., Dunning, G., Valverde, P., Burgess, J., and Brown, M. 1994. Arenig and younger evolution of the Gander margin: a comparison of the New Brunswick and Newfoundland segments. New Perspectives in the Appalachian Caledonian Orogen, Geological Association of Canada NUNA Conference, Program and Abstracts, p. 28.

Williams, H. 1972. Stratigraphy of Botwood map-area, northeastern Newfoundland. Geological Survey of Canada, Open File 113, $98 \mathrm{p}$.

1979. Appalachian orogen in Canada. Canadian Journal of Earth Sciences, 16, pp. 792-807.

1993. Stratigraphy and structure of the Botwood Belt and definition of the Dog Bay Line in northeastern Newfoundland. Geological Survey of Canada, Paper 93-1D, pp. 19-27.
1994. The Dunnage Melange, Newfoundland, revisited. Geological Survey of Canada, Current Research 1994-D, pp. 23-32.

Williams, H. and Stevens, R.K. 1974. The ancient continental margin of eastern North America. In The geology of continental margins. Edited by C.A. Burk and C.L. Drake. SpringerVerlag, New York, pp. 781-796.

Williams, H., Colman-Sadd, S.P., and Swinden, H.S. 1988. Tectono-stratigraphic subdivisions of central Newfoundland. Geological Survey of Canada, Paper 88-1B, pp. 91-98.

Williams, H., Currie, K.L., and Piasecki, M.A.J. 1993. The Dog Bay Line : a major Silurian tectonic boundary in northeast Newfoundland. Canadian Journal of Earth Sciences, 29, pp. 2481-2494.

Williams, S.H. 1993. More Ordovician and Silurian graptolites from the Exploits Zone, Newfoundland. Newfoundland Department of Mines and Energy, Geological Surveys Branch, Report 93-1, pp. 311-315.

Williams, S.H., O'Brien, B.H., Colman-Sadd, S.P., and O'Brien, F.H.C. 1992. Dunnage Zone graptolites: an extension of the age range and distribution of certain Ordovician formations of the Exploits Subzone. Newfoundland Department of Mines and Energy, Geological Surveys Branch, Report 92-1, pp. 203-209.

Wonderly, P.R. and Neuman, R.B. 1984. The Indian Bay formation: fossiliferous early Ordovician volcanogenic rocks in the northern Gander Terrane, Newfoundland and their regional significance. Canadian Journal of Earth Sciences, 21, pp. 525-532.

Wu, T.W. 1978. Structural, stratigraphic and geochemical studies of the Horwood Peninsula area, northeast Newfoundland. M.Sc. thesis, Brock University, Saint Catherines, Ontario, $185 \mathrm{p}$. 